\title{
Financial Management Practices Among Micro Enterprises and their Implications for Loan Repayment: A Case of Solidarity Group Lending of DCB Commercial Bank in Dar es Salaam
}

\author{
Daudi Kitomo $^{1}$, Robson Likwachala ${ }^{1} \&$ Cornelio Swai ${ }^{1}$ \\ ${ }^{1}$ Business and Entrepreneurship Studies Department, National Institute of Transport, Dar es Salaam, Tanzania \\ Correspondence: Daudi Kitomo, Business and Entrepreneurship Studies Department, National Institute of \\ Transport, Dar es Salaam, Tanzania. Tel: 255-755-844-939. E-mail: davidkitomo@gmail.com
}

Received: September 17, 2020

Accepted: November 15, 2020

Online Published: November 25, 2020

doi:10.5539/ijef.v12n12p122

URL: https://doi.org/10.5539/ijef.v12n12p122

\begin{abstract}
The aim of this study was to determine the implications of financial management practices among micro enterprises for loan repayment. The study was confined to Solidarity Group Lending (SGL) customers of DCB Commercial Bank Plc (DCB). Specific objectives included: to identify common practices of managing finances among SGL customers; to determine the extent to which the commonly identified financial management practices influence loan repayment; and to find out challenges facing SGL customers during loan repayment in DCB. A case study research design and cluster sampling were used while data were collected using questionnaires from 80 respondents. Data were analyzed using multiple regressions, and simple descriptive statistics of frequencies, percentages, mean, and range. Results indicate that the common practices of managing finances among the respondents were cash holding $73.8 \%(n=59)$ and short term investments $38.8 \%(n=31)$. Regression results revealed that about $70 \%$ of variations in ease of loan repayment is influenced by cash holding and short term investment techniques at $\mathrm{p}=0.000$ level of significance (i.e. $\mathrm{R}=0.841, \mathrm{R}^{2}=0.707$ and $\mathrm{p}<0.05$ ). Key challenges of loan repayment among the respondents were: losses from business (82.6\%), payment delays from debtors $(67.5 \%)$, and difficulty in managing group members to attend their respective loan centers $(72.6 \%)$. The study recommends that SGL customers need to be educated and sensitized on various financial management techniques and their implications so that they select appropriate techniques in managing profitability and liquidity in their businesses to enhance smooth loan repayment.
\end{abstract}

Keywords: financial management practices, loan repayment, micro enterprises, SGL customers

\section{Introduction}

For majority of micro and small enterprises, borrowing has been one of key sources of finance for funding their business operations, particularly at the growth stage (Wahab \& Abdesamed, 2012). According to the Pecking Order theory in financial management, debt capital is the second preferred source of capital to share capital (equity) after the owner has exhausted internal sources of finance (Jibran, Wajid, Waheed, \& Muhammad, 2012). Usually, loan (debt capital) as a source of business finance does not dilute ownership of the business compared to share capital which normally invites other external funders who in the long run might claim for a bigger share of business ownership and retain significant power of control (Jude \& Adamou, 2018). In terms of cost, loan is considered to be a cheaper source of capital compared to equity for two main reasons: its cost (interest) is fixed and it is a tax-deductible expense (Bracker, Lin, \& Pursley, 2018). The repayment of loan therefore involves fixed settlement of cash to the lender in a specific interval of time.

Despite the fact that large corporations seem to have an upper hand in accessing loan facilities due to their well-established nature and well-kept accounting systems as compared to small businesses (World bank, 2018); evidence shows that in recent years, most financial institutions have identified the micro and small enterprises sub-sector as an important segment for lending (Abanis, Sunday, Burani, \& Eliabu, 2013). This is evident through lending programmes established specifically for micro and small enterprises by various commercial banks such as solidarity group lending (SGL) programme among others (DCB Commercial Bank, 2018). Therefore, given the role played by the borrowed capital and its associated risks, the question of ability of an enterprise to repay the loan cannot be under estimated. 


\subsection{The Role of Micro Enterprise in Economy}

According to Micro, Small and Medium Enterprises (MSME) Baseline Survey Report (2012), a micro enterprise is an enterprise which employs one to four employees. In terms of capital investment, a micro enterprise is the one with a capital of up to five million Tanzania Shillings (MSME Baseline Survey Report, 2012). Due to its nature of ease of entry and relatively low capital investment, informal and micro enterprise segment tends to have substantially many operators; in fact, it is the sub-sector of economy with the largest number of operators, particularly in most of developing countries (Abanis et al., 2013). United Nations Economic and Social Commission for Asia and the Pacific (UNESCAP, 2010) indicates that informal and micro enterprise segments account for over 50\% of non-agricultural employment in many developing countries, thus their role in economic growth cannot be under estimated. Further, the informal and micro enterprise sector in sub-Saharan Africa is the leading sector across the continent, particularly in manufacturing, trade, finance and mining (Kongolo, 2010).

Economic studies indicate that the potential growth nature of micro enterprises tends to attract financial institutions to extend lending services to the enterprises. According to Bertuch-Samuels (2019), local banking platforms are likely to support accessibility to finance among micro and small firms and thereby contributing to a more inclusive growth. According to CRDB bank annual report (2018), MSME have remained to be a critical sub-sector of economy for lending programmes by many financial institutions in Tanzania. Also, the Tanzania Development Vision 2025 indicates that the MSME sector is one of vibrant contributors to long-term development of the country (Mallya, 2000). Such recognition and focus to small businesses in national development plans have catalyzed financial institutions to consider advancing loans to the MSME sector. It should be noted that in most cases, the rise of small business is a result of successful growth of micro enterprises (Nawai \& Shariff, 2010).

\subsection{Factors Affecting Ability to Repay Loans Among Micro and Small Business}

Despite the critical role played by micro and small enterprises in economies, high rate of business failure among the enterprises in developing countries have attracted attention of researchers to investigate possible causes, implications as well as possible remedies (Fatoki, 2014). Various studies done have indicated that some of the factors contributing to micro and small business failures are internal, such as those related to poor attitudes towards customers and poor managerial skills. Also, other factors are external, such as increasing costs of running business and lack of finance among others (National Baseline Survey Report, 2012). Lack of finance has been attributed to inability of many micro and small enterprises to access loan capital due to low financial literacy possessed by the operators (Chimucheka \& Rungani, 2013). Further, Bhunia (2012) points out that among factors that hinder growth of micro and small businesses is inadequate management of capital and financial structures, particularly, poor management of borrowed capital. In addition, the National Baseline Survey Report (2012) in Tanzania indicates that among key reasons for majority closure of micro and small enterprises is insufficient working capital.

Loan repayment for majority of micro and small businesses has been an issue of concern, in the sense that a number of the enterprises have shown high rate of defaulting while others have been honoring their repayment at unexpected slow rate (Wahab \& Abdesamed, 2012; Nawai \& Shariff, 2010). Frequent debt restructuring which is an indication of difficulty in loan repayment has been order of the day among micro enterprises, particularly in developing countries. This has partly been attributed to the problem of information asymmetry between lenders and borrowers (Chimucheka \& Rungani, 2013). Also, since majority of micro business do not have good practices of financial management such as bookkeeping and accounts analysis, lenders face difficulties in assessing credit worthiness of such businesses (Agyei-Mensah, 2011). Hence, "it can be because of information asymmetry that banks usually end up making unprofitable loans" (Chimucheka \& Rungani, 2013, p. 19) In some cases, a number of micro and small businesses have found themselves in a situation of over indebtedness (Mpogole et al., 2012; Wahab \& Abdesamed, 2012; Makorere, 2014). Default behaviors of borrowers, inability to assess financial risks, poor business plans, and low level of financial literacy among other factors have contributed to difficulty in loan repayment among micro and small business operators in most of developing countries (Jindrichovska, 2013; Ongesa et al., 2014). Literature on business management underscore that the importance of loan repayment cannot be under estimated in analyzing business sustainability; therefore, investigating factors affecting loan repayment is crucial in assessing profitability and liquidity of a business entity (Jote, 2018; Chimucheka \& Rungani, 2011).

Other researchers who have attempted to study factors affecting the ability of a business enterprise to repay borrowed capital have concluded on four main dimensions of factors; namely, lender characteristics, borrower 
characteristics, firm characteristics, and loan characteristics (Derban, Binner, \& Mullineux, 2005; Nawai \& Shariff, 2010). Lender characteristics comprise among other aspects, availability of money to lend, internal policies, and requirements put in place for borrowers, including screening procedures and amount of time taken for loan approval (Ochung, 2013). Firm characteristics on the other hand entail non-financial services including training, elementary literacy, and health services among others which have an impact in enhancing repayment efficiency (Godquin, 2004). Other firm-related factors include negative macroeconomic effects such as rise in interest rates and other economic-related shocks to various sectors which in totality affect cost and ease of doing business (Ibrahim \& Shariff, 2016). Loan characteristics entail suitability of the loan type to the borrower and variety in loan programmes offered by the lenders (Derban, Binner, \& Mullineux, 2005). Borrower-related elements that affect loan repayment include erratic behavior, socio-economic environment of a borrower and financial management practices among other individual entrepreneurial attributes (Acs, Markus, \& Szerb, 2010; Shane \& Cable, 2003). This study is confined to borrower-related factors, particularly, financial management practices. This is due to the fact that the dimension of financial management practice is relatively wide and inconclusive in terms of its effect on loan repayment. It should be noted that, in the context of this study, ease of loan repayment entails less frequency of loan restructuring or deviations from the date the loan was to be repaid by a micro enterprise.

\subsection{Financial Management Practices}

Financial management practice is a wide concept and encompasses activities related to financial record keeping of an entity as well as budgeting, reporting, cash flow management, capital planning, and working capital management among other financial management tasks (Turyahebwa, Sunday, \& Ssekajugo, 2013; Obazee, 2019). Studies in finance and investment show that financial management practices play a great role in business sustainability (Rahman, Rahman, \& Belas, 2017; Agyei-Mensah, 2011). For example, Abanis et al. (2013) conducted a study on financial management practices in SMEs in selected districts in Western Uganda. Results of their study reveal that majority of SMEs struggle to grow because the extent of financial management is low. It was observed that poor bookkeeping and inadequate accounts analysis were among factors hindering access to finance by most of small business. It should be noted that proper bookkeeping and accounting is critical for assessing financial strength of an entity and hence it is one of pre-requisite when a business entity is seeking loan capital from financial institutions (Wood \& Sangster, 2012).

A study by Waweru and Ngugi (2014) on the influence of financial management practices on the performance of micro and small enterprises in Kenya, indicates that proper working capital management has a significant positive impact on performance of an enterprise. It is pointed out in their study that financial innovation and proper use of proceeds to invest will ensure stability of the small enterprises and increase chance of access to finance. In a similar perspective, Van Horne and Wachowicz (2012) divulge that efficient management of proceeds (cash) and investment in marketable securities are some of key financial management practices which are essential in ensuring liquidity and access to more capital required by a business firm. This is why companies strive to maintain adequate cash balances by employing various cash management models to determine optimal cash requirement (Ross, Westerfield, \& Jordan, 2010).

In addition, the art of capital planning, fixed asset management, financial accounting and analysis, and investment are indispensable practices in managing both internal and external (borrowed) capital (Butt, Hunjra, \& Ur-Rehman, 2010). According to Madura and Fox (2011), fixed asset management involves the choices of business projects in which the asset will be optimally utilized. "Fixed assets affect long term sustainability of firms which may affect liquidity, solvency, and profitability" (Nagaraju, 2018, p. 876). Poor utilization of fixed asset leads to tremendous financial cost which impairs cash inflows. Therefore, effective management of fixed assets cannot be underestimated for proper liquidity and loan management. Financial accounting and analysis on the other hand involve critical examination of accounting records kept by an enterprise or sole trader to determine trends in costs, cash flows, and capital growth (Wood \& Sangster, 2012). This is essential in measuring liquidity and profitability, and hence making sound financing decisions (Obazee, 2019). Accounts analysis can however be assessed if the owner of the business keeps proper records of accounting. Irrespective of whether it is the owner or hired-manager, if the financial decisions are erroneous, performance of the company especially in terms of profitability and liquidity will be adversely affected (Nagaraju, 2018).

Capital planning in this context refers to the capital maintenance concept which is an accounting concept founded on the principle of recognizing company's income after assessing that the revenue obtained has fully recovered costs incurred (Wood \& Sangster, 2012). According to ACCA (2010), an entity attains capital maintenance when the amount of its capital at the end of a period is unchanged from that at the beginning of the respective period. Although the concept of capital maintenance is twofold: financial and physical, for the purpose 
of this study, only the financial capital maintenance is being referred to. Financial capital maintenance is only confined within the actual funds available at the beginning and the end of a stated accounting cycle. It usually does not consider the assessment of other capital assets (Emile Woolf's, 2013). It should be noted that capital planning is critical because it helps to establish whether the capital is increasing (profit is being made) or it is decreasing (losses are being made). Therefore, this aspect of financial management practice becomes essential in assessing ability of an enterprise in repaying its loans.

\subsection{Empirical Literature and Problem Setting}

Asgedom, Desta, and Bahita (2015) attempted to study factors affecting group loan repayment performance at Dedebit Credit and Saving Institutions in Mekelle Ethiopia. Results of their study revealed seven variables which were statistically significant in group loan repayment performance. These were: loan purpose, understanding monthly sales of the group members, group members regular visits other group members, knowing each other before groups are formed, group members to pressure on other members to repay, penalty, and group members' help. In a similar viewpoint, Jote (2018) on determinants of loan repayment in Microfinance Institutions (MFIs) in Gedeo Zone Ethiopia, indicates that education level, method of lending, and income from activities financed by loan are among key factors affecting ability of a business entity to repay borrowed capital.

Rahman, Rahman, and Belas (2017) also conducted a study on determinants of SME finance from three Central European countries, namely: Czech Republic, Slovak Republic, and Hungary. Results indicate that "micro firms and firms owned and operated by women, experience a shortage of credit from banks" (p. 264). It was pointed out in their study that there is a positive correlation between pledge of security and access to financial services. Further, innovative ways of financial management were found to attract a significant amount of credit from financial institutions. In line with these findings, Abanis, Sunday, and Ssekajugo (2013) reveal that financial management practices account for 38\% of variation in business performance of SMEs. Their findings also indicate that management of working capital predicts over $22 \%$ of the variation in performance of a business.

Other studies such as Ramanujam and Vidya (2018), as well as Gutu, Mulugeta, and Birlie (2017) have studied on credit repayment behaviours of borrowers and determinant factors affecting loan repayment performance of women borrowers respectively. Both studies are to a great extent skewed to demographic factors. Findings from both studies indicate that there was no significant relationship between the demographic elements of borrowers and the credit repayment performance of MSME. Moreover, Makorere (2014) on factors affecting loan repayment behavior in Tanzania points out diverse factors such as interest rate, grace period, profitability, and moral hazards as among major factors affecting loan repayment behavior among MSMEs. In a similar vein, Ochung (2013) in Kenya, indicates that ceteris paribus, individual borrower factors such as those related to demographic, type of account operated, as well as years of experience a borrower has with a particular bank determine repayment or non-repayment of loan.

For the past two decades, lending programmes for MSMEs have become famous among banks and MFIs (Bank of Tanzania, 2018; Ongesa et al., 2014). This has been attributed to diverse factors, including growth in mobile money technologies, increase in financial products, and potential growth nature of MSMEs among other factors. In addition, Kodongo and Kendi (2013) note that "group lending programme is more effective than individual lending programme in mitigating the risk of default among borrowers" (p. 106). Solidarity Group Lending (SGL) scheme in DCB Commercial bank Plc is among lending programmes established by various financial institutions to cater for financial needs among MSMEs in Tanzania. The DCB Commercial Bank Plc (DCB) which was established in 2001 as Dar es Salaam Community Bank Plc introduced the SGL programme in early 2000's. The bank changed its name in February 2012 (Alfred, 2005).

Solidarity Group Lending is the process of advancing loans of relatively small amount, focusing on group guarantee of five people as security with weekly regular repayments and deposits (DCB Commercial Bank, 2012). The purpose of the loan is to enable households and youth have access to capital for their economic activities which usually have potential for employment creation (DCB Commercial Bank, 2018). The scheme (SGL) has proved to be a supportive programme for its customers, although management of the groups and effective loan repayment have to some degree remained to be challenging. Despite the fact that data indicate that some MFIs prefer individual lending programmes (Kodongo \& Kendi, 2013), DCB and other commercial banks in Tanzania have maintained group lending programmes for such low-income groups.

At this point it is imperative to note that although a number of studies have been done on financial management practices and loan repayment, there is little information on the direct link between financial management practices and loan repayment. Most of reviewed studies such as Abanis et al. (2013), Waweru and Ngugi (2014), Rahman et al. (2017), and Turyahebwa et al. (2013) have attempted to determine financial management practices 
in relation to either firm performance or access to finance. Also, working capital management, particularly receivables and inventory management, as one of the aspects of financial management practices, has been featured mostly in those studies compared to other aspects. Even those studies on factors affecting loan repayment such as that of Ochung (2013), Moakorere (2014), Asgedom et al. (2015), and Jote (2018) have identified either demographic, regulatory, behavioral, or education level in general as determinants of loan repayment. Little is mentioned of the implications of financial management practices on loan repayment. Further, Nawai and Shariff (2010) indicate that, since it is difficulty for lenders to predict the behaviors of their clients as being honest or not, there is a need to intensify clients' analysis and devise other mechanisms to improve loan repayment in microcredit programs. This study therefore is an attempt to address the gap by determining the influence of financial management practices such as cash budget, short-term investment, fixed asset management, cash holding, and working capital (among micro enterprise operators) on loan repayment. Solidarity Group Lending (SGL) of DCB in Dar es Salaam, as one of tailor-made microcredit programs in the community bank, is used as a case study. Specifically, this study sought to achieve the following objectives:

i. To identify common practices of managing finances among SGL customers.

ii. To determine the extent to which the commonly identified financial management practices influence loan repayment.

iii. To find out challenges facing SGL customers during loan repayment in DCB.

\section{Method}

\subsection{Study Design and Location}

This research is a case study conducted in Dares Salaam, Tanzania, the country's business capital. The study was confined to SGL Customers of DCB in Kinondoni District. The DCB is one of the public listed commercial banks currently operating in Dar es Salaam with branches in various parts of the City, particularly in three districs: Kinondoni, Ilala, and Temeke. The bank has its head quarter in Kinondoni District. The DCB has divided its SGL services in centres. A location is qualified to be a centre if it has about 50 clients (SGL customers). Kinondoni has about 800 SGL customers who are divided in centres of about 50 each (DCB Commercial Bank, 2012). Within the centre, there are other small groups of five members each. Some of these centres are as old as over ten years of operation while some are still relatively new. Among the centres which have been in operation for quite a long time include: Head quarter, Mwenge, Bunju and Kigogo centres. Alfred (2005) however observes that there are situations when centres experience a decreasing number of SGL customers on regular basis amid competition from other emerging MFIs.

It was observed that the SGL customers from these centres are of homogeneous characteristics in terms of economic profiles and types of economic activities they undertake. It should be noted that DCB bank envisages serving the low-income groups section of the Tanzanian population, particularly, in Dar es Salaam City (Alfred, 2005). It was also observed that the common business activities that majority the SGL customers are engaged themselves include food vending, clothing \& tailoring, transport (motor bike), retailing (e.g. kiosk), selling of electronics, financial services (e.g. M-pesa) as well as farming-related activities (poultry farm, dairy farm, animal husbandry/feed etc.).

\subsection{Sample Size and Sampling Techniques}

The homogeneity nature of the population was taken into consideration and the researchers applied cluster sampling technique. According to Bryman and Bell (2011), cluster sampling is appropriate when a study involves interviewing or distributing questionnaire to a "widely dispersed population such as a large region or even a large City" (p. 182). The SGL centres were therefore treated as clusters and the researchers picked four random centres for the consideration under the study. The four centres were picked due to the fact that they are among the old centres which have been in operation for relatively many years as compared to others in the District (DCB Commercial Bank, 2012). The centres picked are Head quarter, Mwenge, Bunju and Kigogo. The researchers applied the principle of $10 \%$ to estimate the sample size. The sample size of 80 was therefore estimated for the study from the target population of 800 .

\subsection{Questionnaire and Data Collection Procedure}

This study was informed by data collected using self-administered questionnaire. The tool was considered appropriate because of the nature of data and statistical techniques for data analysis which the study intended to employ (Pallant, 2013). Therefore, a number of closed, likert type, and a few open-ended questions were used in the questionnaire to provide the respondents with a number of defined response choices (Bryman \& Bell, 2011). This was necessary for the purpose of capturing all important data on demographics of respondents as well as 
information on financial management practices and loan repayment. The tool was tested prior to being administered to the sample of 80 SGL customers. Questionnaire items consisted of questions on: demographic information like sex, age, education level, type of business, and years of business experience; also knowledge of financial management practices, techniques used in managing finances, as well as challenges faced in loan repayment.

Researchers visited the four selected centres (Head quarter, Mwenge, Bunju and Kigogo) to observe and identify respondents for administering the questionnaire between March-April, 2019. Twenty (20) questionnaires were administered in each centre. For the purpose of reaching different small group members within the centres, we had to visit the centres in different days and weeks. This enabled us to reach different respondents from different member groups to participate in the study. Filling in the questionnaire was voluntary and respondents were requested to fill in a questionnaire and return to the researchers before leaving the centres. Where necessary, clarification was given by the researchers to the respondents for proper understanding of the questions and purpose of the study.

\subsection{Data Analysis}

Data were analyzed using both descriptive and inferential statistics. Simple descriptive statistics of frequency, percentages, means, and range were computed. For inferential statistics, a multiple regression was run to test the influence of commonly identified financial management practices on the variations of ease of loan repayment. A $95 \%$ confidence interval was applied in running the regression tests.

\section{Results}

\subsection{Respondent Characteristics}

Characteristics of respondents as described in terms of age, education level, gender, years of experience in business, as well as type of business were descriptively analyzed. These variables were considered important in this study because they provide the general profiles of the respondents (Bryman \& Bell, 2011). The general characteristics of a sample of 80 respondents who were surveyed during the data collection process are shown in table 1 . Approximately, $65.1 \%$ of the respondents are in their early adulthood with ages ranging between 26 and 41 years. It was expected by the researchers that since SGL programme targets low-income earners, then, more youth who are at the stage of beginning self-dependent life would take advantage of the loan scheme as they strive for self-employment. Majority of the respondents (57.5\%) were of secondary education level. Again we expected that the respondents, being business people, would possess some kind of formal education. This was important for understanding of questions and responding to them.

In terms of gender, 55\% of the respondents were females while males were $45 \%$. It was hypothesized that there would be a possibility of having more women than men because anecdotal experience shows that women are more likely to form business groups than their men counterpart. Further, approximately $60.1 \%$ of respondents had over 3 years of experience in business. We had postulated that, given general loan experiences and the oldness of the SGL programme, individuals who have established business already are more likely to approach financial institutions for loan services than those without experience in business. Also, as argued by Zikmund (2003), research respondents need to possess the appropriate experience, training, and attributes that the researcher aims to investigate so as to give the research work required credibility. The respondents' experience therefore was regarded as acceptable in providing reliable information that was required. In terms of business type, majority of the respondents $(25 \%)$ were food vendors followed by $18.8 \%$ clothing and tailoring, $16.3 \%$ engaged in transport (motor bikes), 15\% retail, $11.2 \%$ selling electronics, $10 \%$ small holders farmers and $3.8 \%$ financial services (mobile money business). Table 1 summarizes the respondents' characteristics.

Table 1. Age, Education level, Gender, Years of Experience, and Type of Business of a Respondent

\begin{tabular}{lccc}
\hline Variable & Value & Frequency & Per cent \\
\hline Age group & $18-25$ & 17 & 21.3 \\
& $26-33$ & 23 & 28.8 \\
& $34-41$ & 29 & 36.3 \\
& $42-49$ & 9 & 11.3 \\
& 50 and above & 2 & 2.5 \\
\hline
\end{tabular}




\begin{tabular}{lccc}
\hline Education level & Primary education & 15 & 18.8 \\
& Secondary education & 46 & 57.5 \\
& Diploma holders & 12 & 15 \\
& Bachelor's degree and above & 7 & 8.8 \\
Gender & Total & 80 & 100 \\
& Male & 36 & 45 \\
Years of business experience & Female & Total & 55 \\
& Below 1 year & 80 & 100 \\
& $1-3$ years & 9 & 11.3 \\
Type of business & $3-5$ years & 23 & 28.8 \\
& 5 years and above & 27 & 33.8 \\
& Total & 21 & 26.3 \\
& Retailing & 80 & 100 \\
& Food vending & 12 & 15 \\
& Transport (motor bikes) & 20 & 25 \\
& Clothing and tailoring & 13 & 16.3 \\
\hline
\end{tabular}

\subsection{Respondents' Monthly Average Income}

For the purpose of assessing financial management practices among the surveyed respondents, it was important to get data on average monthly income. The study revealed that on average, monthly income levels among the respondents range between Tanzania Shillings (TZS) 150,000 and 600,000. This is an indication that the bank, through SGL programme, serves mostly the low-income population, particularly those economically active poor people who engage in micro and small businesses. Table 2 indicates monthly average income of the respondents.

Table 2. Monthly average income

\begin{tabular}{ccccccc}
\hline & $\mathrm{N}$ & Range & Minimum & Maximum & Mean & Std. Deviation \\
\hline $\begin{array}{c}\text { Minimum Average } \\
\text { income per month }\end{array}$ & 80 & $300,000.00$ & $150,000.00$ & $450,000.00$ & $221,250.00$ & $111,881.21$ \\
$\begin{array}{c}\text { Maximum Average } \\
\text { income per month }\end{array}$ & 80 & $300,000.00$ & $300,000.00$ & $600,000.00$ & $395,000.00$ & $120,275.11$ \\
\hline
\end{tabular}

\subsection{Financial Management Practices Among Surveyed SGL Customers}

This study sought to find out the common financial management practices employed by the respondents and then determine the degree to which such practices predict the ease in variations of loan repayment. Financial management literature indicate that among financial management practices employed by business firms include working capital, fixed asset management, capital budgeting, pay-back period, accounts analysis, capital planning, cash budget, cash holding management, and short-term investment among others (Van Horne \& Wachowicz, 2012; Ross, Westerfield, \& Jordan, 2010). This study explored concepts related to application of these financial management practices in terms of how they are employed by different firms and their contributions to business sustainability and access to more capital. The practices were then tested against the respondents to establish the common practices used by SGL customers. Table 3 to table 5 show the results of the financial management practices among the respondents.

\subsection{Working Capital, Capital Budgeting and Fixed Asset Management Practices}

It was revealed that respondents still have little knowledge on working capital management as only $2.5 \%$ agreed that they use the practice. The rest $(97.5 \%)$ were neutral which means they could not articulate how they apply working capital management in their business. Again $96.3 \%$ could not show whether they practice capital budgeting in running and managing their business operations. It could be understood probably that given the size of their businesses, there is likelihood that most of them do not possess significant amount of capital assets. This is 
also revealed on the question of fixed asset management practice where $100 \%$ of respondents were neutral. Table 3 summarizes the results.

Table 3. Working capital, capital budgeting and fixed asset management techniques

\begin{tabular}{llcc}
\hline Variable & Value & Frequency & Per cent \\
\hline Working capital & Agree & 2 & 2.5 \\
& Neutral & 78 & 97.5 \\
& Total & 80 & 100 \\
Capital budgeting & Agree & 2 & 2.5 \\
& Neutral & 77 & 96.3 \\
& Non-response & 1 & 1.3 \\
Fixed asset management & Total & 80 & 100 \\
& Neutral & 80 & 100 \\
\hline
\end{tabular}

\subsection{Payback Period, Financial Accounting, and Capital Planning}

As shown in table 4, results indicate that only $5 \%$ of the respondents use payback period in managing their finances. On the other hand, only $2.6 \%$ of respondents apply financial accounting and analysis, while $2.5 \%$ apply the knowledge of capital planning. This reveals that more than $90 \%$ of the surveyed population have either no knowledge of the three financial management practices (Payback Period, Financial Accounting, and Capital planning) or do not see their importance in managing businesses. It should be noted that payback period is an important technique of managing finances, liquidity, and loans especially in small businesses. Therefore, it was surprising that the technique is not common among the respondents. Researchers had hypothesized that the payback period would be among common financial management practices among micro and small business.

Table 4. Payback period and financial accounting, and capital planning

\begin{tabular}{|c|c|c|c|}
\hline Variable & Value & Frequency & Per cent \\
\hline \multirow[t]{4}{*}{ Payback period } & Strongly Agree & 2 & 2.5 \\
\hline & Agree & 2 & 2.5 \\
\hline & Neutral & 76 & 95 \\
\hline & Total & 80 & 100 \\
\hline \multirow[t]{4}{*}{ Financial Accounting and analysis } & Strongly Agree & 1 & 1.3 \\
\hline & Agree & 1 & 1.3 \\
\hline & Neutral & 78 & 97.5 \\
\hline & Total & 80 & 100 \\
\hline \multirow[t]{3}{*}{ Capital planning } & Strongly Agree & 2 & 2.5 \\
\hline & Neutral & 78 & 97.5 \\
\hline & Total & 80 & 100 \\
\hline
\end{tabular}

\subsection{Cash Budgeting, Cash holding, and Short Term Investment Techniques}

With regard to cash budget, cash holding, and short term investment techniques, it was found out that cash budget was not a common technique of managing finances among the respondents. This was revealed by $97.5 \%$ of the respondents who were neutral on whether they apply the technique. It was however interesting to find out that about $73.8 \%$ employ cash holding as the main financial management practice to manage loan repayments. Approximately $38.8 \%$ use short-term investment in managing their loans. The practices therefore were found to be relatively more common as compared to other practices which majority of respondents could not use or not interested. The two practices (Cash holding and short-term investment) however were not mutually exclusive, meaning, a person could employ both. Table 5 is a snapshot of the results. 
Table 5. Cash budgeting, cash holding, and short term investment techniques

\begin{tabular}{|c|c|c|c|}
\hline Variable & Value & Frequency & Per cent \\
\hline \multirow[t]{3}{*}{ Cash budget } & Agree & 2 & 2.5 \\
\hline & Neutral & 78 & 97.5 \\
\hline & Total & 80 & 100 \\
\hline \multirow[t]{5}{*}{ Cash holding } & Strongly Agree & 42 & 52.5 \\
\hline & Agree & 17 & 21.3 \\
\hline & Neutral & 19 & 23.8 \\
\hline & Disagree & 2 & 2.5 \\
\hline & Total & 80 & 100 \\
\hline \multirow[t]{4}{*}{ Short-term investment } & Strongly Agree & 19 & 23.8 \\
\hline & Agree & 12 & 15 \\
\hline & Neutral & 49 & 61.3 \\
\hline & Total & 80 & 100 \\
\hline
\end{tabular}

\subsection{Most Preferred Financial Management Practices and the Way They Are Employed}

Researchers were interested in establishing the commonly used practices of managing finance and how the practices are employed. Results indicate that $45 \%$ of those who prefer to hold cash, make use of local safe to hold money while $7.5 \%$ make use of mobile money platforms (e.g M-pesa, tigo-pesa, Airtel money, etc.) to keep money for managing their loans. The results were interesting since the use of bank account for cash holding was low. Table 6 summarizes the results.

Table 6. Most preferred financial management practices and the way they are employed

\begin{tabular}{clcc}
\hline Financial Management Technique & Method of investing/Holding cash & Frequency & Per cent \\
\hline \multirow{3}{*}{ Short term investment } & Investing in other related business & 24 & 30 \\
& Ploughing back and expanding the business & 9 & 11.3 \\
& VICOBA & 5 & 6.3 \\
Cash holding & The use of Local safe/Cash holding & 36 & 45 \\
Total & The use of Mobile money saving (Mpesa) & 6 & 7.5 \\
\hline
\end{tabular}

\subsection{The Extent to Which the Commonly Identified Financial Management Practices Affect Ease of Loan Repayment}

As discussed in section 3.6, the commonly identified financial management practices among the surveyed respondents are cash holding and short-term investments. Therefore, researchers were interested in determining the extent to which the two variables (practices) affect the variations in ease of loan repayment. As noted before, ease of loan repayment is generally viewed in terms of less frequency in loan restructuring or de viations from the date the loan was to be repaid. Hence, a regression was run to find out the influence of cash holding and short-term investment practices on ease of loan repayment. Results (Table 7) indicate that $70 \%$ of variations in ease of loan repayments can be attributed to the joint effect of the predictor variables (cash holding and short-term investment). The ANOVA results as shown in table 8 reveals that the relationship was significant ( $\mathrm{p}=$ 0.000 ) in predicting how cash holding and short term investments influence loan repayment.

Table 7. Regression model summary

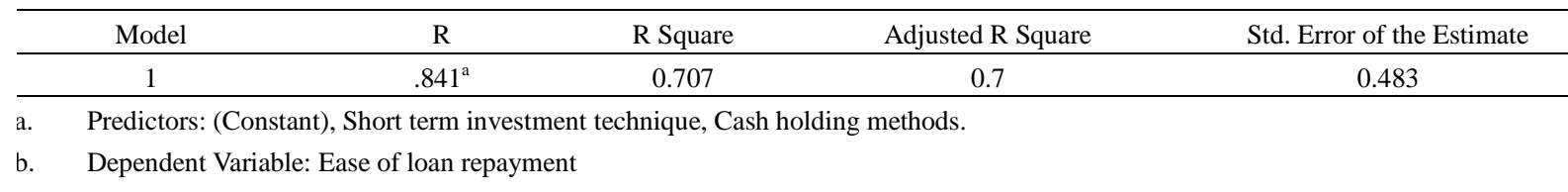

Table 8. Regression ANOVA

\begin{tabular}{lccccc}
\hline Model & Sum of Squares & Df & Mean Square & F & Sig. \\
\hline Regression & 43.498 & 2 & 21.749 & 93.09 & $.000^{\mathrm{b}}$ \\
Residual & 17.99 & 77 & 0.234 & & \\
Total & 61.488 & 79 & & & \\
\hline
\end{tabular}


Further, since the interest of researchers was not to construct a regression equation but rather to compare the contribution of each identified variable, the standardized coefficients were used to check the influence of each of the two variables (Pallant, 2013). Thus, the coefficients for the two variables (Cash holding and short term investments) were 0.765 and -0.141 respectively. This means that a unit change in cash holding leads to a 0.765 change in ease of loan repayment. Similarly, a unit change in short term investment causes a -0.141 change in ease of loan repayment. In other words, a unit of cash put in short term investment lowers the ease of loan repayment by 0.141 at least in the short run. Table 9 summarizes the coefficients results.

Table 9. Coefficients of the regression analysis

\begin{tabular}{|c|c|c|c|c|c|c|}
\hline \multirow{2}{*}{ Model } & \multicolumn{2}{|c|}{ Unstandardized Coefficients } & \multirow{2}{*}{$\begin{array}{c}\text { Standardized Coefficients } \\
\text { Beta }\end{array}$} & \multirow[t]{2}{*}{ Sig. } & \multicolumn{2}{|c|}{ Collinearity Statistics } \\
\hline & $\mathrm{B}$ & Std. Error & & & Tolerance & VIF \\
\hline (Constant) & 0.894 & 0.26 & & 0.001 & & \\
\hline Cash holding methods & 0.747 & 0.068 & 0.765 & 0.000 & 0.772 & 1.295 \\
\hline Short term investment technique & -0.146 & 0.073 & -0.141 & 0.048 & 0.772 & 1.295 \\
\hline
\end{tabular}

\subsection{Challenges Faced by SGL Customers in Loan Repayment}

It was important for the researchers to identify key challenges faced by the groups of SGL customers in loan repayments. This was important for improving ease of loan repayment. Findings (as shown in table 10) reveal that on the aspect of losses, $82.6 \%$ of respondents were in agreement that such losses incurred by the businesses were a challenge in meeting loan repayment obligations. Other challenges included difficulty in managing the small group members especially in attending their respective loan centers $(72.6 \%)$ and default by debtors $67.5 \%$. According to the respondents, attending the loan centres is a requirement especially for a borrower to remit cash installments for repaying a loan and presenting status of the going concern of their businesses. Defaults from debtors seems to be relatively less as compared to other aspects of challenges. The reason for this would be the selling practices by most of micro businesses where they make most of their sales in cash and in case of any credit sales, then the maximum debt collection period is one month. Surprisingly, $68.8 \%$ of respondents did not agree on the issue of uncertainty in regulations guiding micro and small businesses. This is an indication that majority of SGL customers are aware of various laws and regulations guiding the running of small businesses. We had hypothesized that majority of informal and micro business operators have low understanding of regulatory requirements in running such businesses.

Table 10. Key challenges faced by SGL customers in loan repayment

\begin{tabular}{llcc}
\hline Variable & Value & Frequency & Per cent \\
\hline Default by customers & Strongly Agree & 28 & 35 \\
& Agree & 26 & 32.5 \\
& Neutral & 26 & 32.5 \\
Difficulty in managing groups & Total & 80 & 100 \\
& Strongly Agree & 21 & 26.3 \\
& Agree & 37 & 46.3 \\
Losses incurred & Neutral & 22 & 27.5 \\
& Total & 80 & 100 \\
& Strongly Agree & 29 & 36.3 \\
Uncertainty with regulations & Agree & 37 & 46.3 \\
& Neutral & 14 & 17.5 \\
& Total & 80 & 100 \\
& Strongly Agree & 3 & 3.8 \\
\end{tabular}

\section{Discussion}

Our results indicate that the common financial management practices among the SGL customers are cash 
holding and short term investments. Other aspects of financial management such as payback period, cash budget, and fixed asset management among others were not common among the surveyed respondents. Except for cash holding and short term investments, the surveyed SGL customers showed little understanding and application of most of the financial management techniques. The cash holding is commonly done through the use of mobile money technology where cash is kept by the use of M-pesa, Air tel money, Tigo pesa, among other mobile money platforms. A few individuals use local safe for keeping cash for managing their loan repayment. It was not surprising for lack of use of bank account to keep their running cash due to conditions imposed on SGL individual customer accounts where there is control of the accounts and restrictions in withdraws. Majority of those who practice short term investments seem to prefer investing in other similar business while a few plough back their savings in their existing business as well as putting in Village Community Banks (VICOBA) shares.

Van Horne and Wachowicz (2012) point out that individuals hold cash for three main purposes: transactions motive, speculative motive, and precautionary motive which are important for day to day operation of a business. The three motives are for liquidity as discussed by John Maynard Keynes in his classical work of "The General Theory of Employment, Interest, and Money" (Ross et al., 2010, p. 824). Nevertheless, when cash kept in excess of required minimum (whether in currency or bank deposits), it tends to incur an opportunity cost. The opportunity cost is the interest income that the cash would earn had it been used in the next best option, such as investment in marketable securities (Ross, Westerfield, \& Jordan, 2012). Effective cash management therefore encompasses efficient collection, disbursement, and investment of the cash. Hence, the principal goal of cash management should be to ensure that sufficient cash is available to finance day to day operations while at the same time idle funds are minimized through careful investment (Srivastava \& Misra, 2011).

Further, there is a trade-off between short term investment practice and loan repayment. From the findings, a unit of currency taken from cash to short term investment reduces ability in meeting loan obligations by 0.141 when other factors are kept constant. This means that if not properly managed, the trade-off between investment and loan repayment may generally have negative impact on the variations in ease of loan repayment. This can be reflected by presence of frequent debt restructuring or deviations from the date the loan was to be repaid, which is an indication of difficulty in loan repayment. Investment is important to ensure performance in profitability of an SME. Waweru and Ngugi (2014) indicate that innovations in financial services, investment activities, risk management practices, and management of working capital collectively, predict performance of SME by $82.8 \%$. This is an indication that the role of investment activities as part of financial management practices cannot be underestimated.

Nevertheless, a critical analysis is required to understand the trade-off between profitability and liquidity. This is because liquid assets suffer an opportunity cost equivalent to either the cost of short-term finance or to the revenue foregone for not investing in profitable ventures (Van Horne \& Wachowicz, 2012). Hence, it is important for a business to establish optimal liquidity in terms of cash and cash equivalent balances necessary to keep for meeting short term debts so that any extra funds can be re-invested in profitable ventures (Srivastava \& Misra, 2011). Therefore, financial institutions can use appropriate cash management models in advising their clients on optimal cash balance to hold for working capital purposes. Any excess cash can be re-invested in marketable securities such as treasury bonds and alike to ensure long-term liquidity and profitability. This is essential for smooth loan repayment.

About $90 \%$ of the surveyed respondents displayed little understanding of most of financial management practices such as payback period, cash budget, fixed asset management, and financial accounting among others. Lack of understanding of these aspects has implications on capital management, including management of debt capital. Madura and Fox (2011) indicate that proper management of fixed asset increases economies of scale and probability for more future cash generation. It therefore boosts ability of an enterprise in managing both short and long-term financial obligations such as meeting loan repayment. Fixed asset management entails choices of business ventures in which the asset will be optimally used. Also, practices such as payback period and cash budget are useful in micro and small businesses. Payback period assists in forecasting the period it takes for an investment to 'pay back' or recoup the initial capital outlay. The use of payback period technique, among other issues, helps in negotiating type of loan and repayment schedule. Cash budget on the other hand assesses the inflow and outflow of funds and thus critical in identifying the point in time when a business may have deficit or less cash and thus arrange for external funding in advance. As argued by Abanis, Sunday, Burani, and Eliabu (2013), book keeping and accounts analysis, including cash flow analysis, is essential for ensuring sustainable capital management. It therefore becomes critical for operators in micro enterprises to possess such knowledge of financial management practices because it has significant impact in loan acquisition and repayment.

As revealed in the findings, key challenges faced by the micro enterprises in meeting loan repayment obligations 
include losses from trading, management of small groups within centres, and defaults from debtors. It should be noted that these factors, particularly losses and default by debtors affect firm's cash flows which in the long run impairs ability of the firm in meeting its financial obligations. The likely impacts of such challenges include unnecessary debt restructuring or nonconformity with the loan repayment schedule which is an indication of difficulty in loan management. Further, it was thought-provoking to see $68.8 \%$ of respondent did not agree with the question of low level of awareness of regulations guiding micro and small businesses. This is an indication that majority of micro enterprise operators are aware with various laws regulating their respective businesses. The researchers have attributed this awareness to the changes in such laws particularly in recent years during the fifth phase government where all individuals operating in informal and micro enterprise sector are required to have an entrepreneur's identification card (Tanzania Revenue Authority (TRA), 2018). This card is issued by the Central government at an annual fee of Tanzania Shillings twenty thousand. The use of this card has removed duplication of regulations and possibility of multi-taxes because prior to its issuance, necessary screening will have been done and hence the entrepreneur will be aware of regulations. World Bank (2014) indicates that lack of awareness towards business regulations is among factors contributing to loan failures among small business communities.

\section{Conclusion}

This study intended to determine the implications of financial management practices among micro enterprises for loan repayment. Among various financial management practices which may impact loan repayment, cash holding and short term investment were found to be critical. Although the study was confined to SGL customers of DCB, the findings stimulate a focus on how financial management practices in micro and small businesses can play a role in management of borrowed capital. The results also are thought-provoking in terms of how financial management should be taught and understood in the context of micro enterprises as opposed to traditional context of large corporations.

\section{References}

Abanis, T., Sunday, A., Burani, A., \& Eliabu, B. (2013). Financial management practices in small and medium enterprises in selected districts in western Uganda. Research Journal of Finance and Accounting, 4(2), 29-42.

Acs, J. Z., Markus, G., \& Szerb, L. (2010). Measuring the entrepreneurial behavior of the established businesses: An individual and a country-level investigation. London: London Imperial College.

Agyei-Mensah, B. K. (2011). Financial management practices of small firms in Ghana: An empirical study. African Journal of Business Management, 5(10), 3781-3793. https://doi.org/10.2139/ssrn.1597243

Alfred, M. H. (2005). Evaluation of microcredit solidarity group lending: The case of Dar es Salaam Community Bank Ltd.(DCB). Unpublished Master thesis, Open University of Tanzania.

Asgedom, A. K., Desta, T. S., \& Bahita, G. H. (2015). Factors Affecting Group Loan Repayment: A case of Dedebit Credit and Saving Institution (DECSI), Mekelle, Ethiopia. Journal of Poverty, Investment and Development, 10, 22-43.

Association of Certified Chartered Accountants (ACCA). (2010). Financial Accounting. London: BPP Learning Media Ltd.

Bank of Tanzania (BoT). (2018). National financial inclusion framework 2018-2022. Dar es Salaam: BoT.

Bertuch-Samuels, A. (2019). Financial sector development-the role of effective local banking structures. Background paper for the 2019 UN inter-agency task force report on financing for development.

Bhunia, A. (2012). The impact of liquidity on profitability: A case study of FMCG companies in India. Research and Social practices in Social Sciences, 7(2), 44-58.

Bracker, K., Lin, F., \& Pursley, J. (2018). Business finance essentials. https://www.researchgate.net/publication/329222662

Bryman, A., \& Bell, E. (2011). Business research methods (3rd ed.). New York: Oxford University Press.

Butt, B. Z., Hunjra, A. I., \& Ur-Rehman. (2010). Financial Management Practices and Their Impact on Organizational Performance. World Applied Sciences Journal, 9(9), 997-1002. https://doi.org/10.2139/ssrn.1750391

Chimucheka, T., \& Rungani, E. C. (2011). The impact of inaccessibility to bank finance and lack of financial management knowledge to small, medium and micro enterprises in Buffalo City Municipality, South Africa. 
African Journal of Business Management, 5(14), 5509-5517. http://www.academicjournals.org/AJBM.

Chimucheka, T., \& Rungani, E. C. (2013). Obstacles to accessing Finance by Small Business Operators in the Buffalo City Metropolitan Municipality. East Asian Journal of Business Management, 3, 17-22. https://doi.org/10.13106/eajbm.2013.vol3.no2.23

CRDB bank. (2018). Annual report. Dar es Salaam: CRDB.

DCB Commercial Bank. (2012). Annual report. Dar es Salaam: DCB.

DCB Commercial Bank. (2018). Annual report. Dar es Salaam: DCB.

Derban, W. K., Binner, J. M., \& Mullineux, A. (2005). Loan repayment performance in community development finance institutions in the UK. Small Business Economics, 25, 319-332. https://doi.org/10.1007/s11187-004-6483-y

Emile, W. (2013). Financial Accounting. Berkshire: Emile Woolf Publishing Ltd.

Fatoki, O. (2014). The Causes of the Failure of New Small and Medium Enterprises in South Africa. Mediterranean Journal of Social Science, 5(20), 920-927. https://doi.org/10.5901/mjss.2014.v5n20p922

Godquin, M. (2004). Microfinance repayment performance in Bangladesh: How to improve the allocation of loans by MFIs. World Development, 32(11), 1909-1926. https://doi.org/10.1016/j.worlddev.2004.05.011

Gutu, F., Mulugeta,W., \& Birlie, B. (2017). Determinant factors affecting loan repayment performance of women borrowers from micro finance institutions in Southwest Ethiopia: Evidence from four woredas around Gilgel Gibe hydroelectric power dam. Global Journal of Management and Business Research, 17(1), 42-52. https://journalofbusiness.org/index.php/GJMBR/article/view/2229

Ibrahim, M. A., \& Shariff, M. N. M. (2016). Mediating role of access to finance on the relationship between strategic orientation attributes and SMEs performance in Nigeria. International Journal of Business and Society, 17, 473-496. https://doi.org/10.33736/ijbs.537.2016

Jibran, S., Wajid, S. A., Waheed, I., \& Muhammad, T. M. (2012). Pecking at pecking order theory: Evidence from Pakistan's non-financial sector. Journal of Competitiveness, 4(4), 86-95. https://doi.org/10.7441/joc.2012.04.06

Jindrichovska, I. (2013). Financial Management in SMEs. European Research Studies, 16(Special Issues on SMEs). https://doi.org/10.35808/ersj/405

Jote, G. G. (2018). Determinants of loan repayment: The case of microfinance institutions in Gedeo Zone, SNNPRS, Ethipia. Universal Journal of Accounting and Finance, 6(3), 108-122. https://doi.org/10.13189/ujaf.2018.060303

Jude, F. A., \& Adamou, N. (2018). Bank Loan Financing Decisions of Small and Medium-Sized Enterprises: The Significance of Owner/Managers' Behaviours. International Journal of Economics and Finance, 10(5), 231-241. http://doi.org/10.5539/ijef.v10n5p231

Kodongo, O., \& Kendi, L. G. (2013). Individual lending versus group lending: An evaluation with Kenya's microfinance data. Review of Development Finance, 3, 99-108. https://doi.org/10.1016/j.rdf.2013.05.001

Kongolo, M. (2010). Job Creation versus Job Shedding and the Rate of SMEs in Development. African Journal of Business, 4(11), 2288-2295.

Madura, J., \& Fox, R. (2011). International Financial Management (2nd ed.). Hampshire: Cengage Learning EMEA.

Makorere, R. F. (2014). Factors affecting loan repayment behavior in Tanzania: Empirical evidence from Dar es Salaam and Morogoro. International Journal of Development and Sustainability, 3(3), 481-492.

Mallya, E. (2000). A critical look at Tanzania's development vision 2025. University of Dar es Salaam.

Mpogole, H., Mwaungulu, I., Mlasu, S., \& Lubawa, G. (2012). Multiple Borrowing and loan repayment: A study of microfinance clients at Iringa, Tanzania. Global Journal of Management and Business Research, 12(4), 96-102.

Nagaraju, S. (2018). A Study on Fixed Asset Management. IAETSD Journal for Advanced Research in Applied Sciences, 5(2), 876-887. http://iaetsdjaras.org/

National Baseline Survey Report. (2012). Micro, Small and Medium Enterprises (MSME) in Tanzania. Financial Sector Deepening Trust (FSDT). 
Nawai, N., \& Shariff, M. N. M (2010). Determinants of repayment performance in microcredit programs: A review of literature. International Journal of Business and Social Science, 1(2), 152-161.

Obazee, A. T. (2019). Exploring Financial Management Practices of Small and Medium-Sized Enterprises in Nigeria. Unpublished Doctoral thesis. Walden University.

Ochung, O. (2013). Factors affecting loan repayment among customers of commercial banks in Kenya: A case of Barclays bank of Kenya, Nairobi County. Unpublished Master thesis. University of Nairobi.

Ongesa et al. (2014). Determinants of Loan Repayment Behaviour of Smallholder Cooperative Farmers in Yewa North Local Government Area of Ogun State, Nigeria: An Application of Tobit Model. Journal of Economics and Sustainable Development, 5(16), 144-153.

Pallant, J. (2013). SPSS Survival Manual (5th ed.). New York: McGraw-Hill Education.

Rahman, A., Rahman, T., \& Belas, J. (2017). Determinants of SME finance: Evidence from three Central European Coutries. Review of Economic Perspective-Narodohospodarsky Obzor, 17(3), 263-285. https://doi.org/10.1515/revecp-2017-0014

Ramanujam, V., \& Vidya, A. (2018). A Study on the Credit Repayment Behaviour of Borrowers. International Research Journal of Business and Management, 9-18.

Ross, S. A., Westerfield, R. W., \& Jaffe, J. (2010). Corporate Finance (9th ed.). Irwin: McGraw Hill.

Ross, S. A., Westerfield, R. W., \& Jordan, B. D. (2012). Fundamentals of Corporate Finance (9th ed.). Irwin: McGraw Hill.

Shane, S., \& Cable, D. (2003). Network Ties, Reputation, and the Financing of New Ventures. Management Science, 48(3), 364-381. https://doi.org/10.1287/mnsc.48.3.364.7731

Srivastava, R., \& Misra, A. (2011). Financial management (2nd ed.). New Delhi: Oxford University Press.

Tanzania Revenue Authority (TRA). (2018). Uzinduzi wa utoaji wa vitambulisho kwa wafanyabiashara wadogo.

Turyahebwa, A., Sunday, A., \& Ssekajugo, D. (2013). Financial management practices and business performance of small and medium enterprises in western Uganda. African Journal of Business Management, 7(38), 3875-3885. https://doi.org/10.5897/AJBM2013.6899

United Nations Economic and Social Commission for Asia and the Pacific (UNESCAP). (2010). Economic and social survey of Asia and the Pacific: Sustaining recovery and dynamism for inclusive development. United Nations publication.

Van Horne, J. C., \& Wachowicz, J. M. Jr. (2012). Fundamentals of Financial Management (13th ed.). New Delhi: PHI Learning.

Wahab, K. A., \& Abdesamed, K. H. (2012). Small and medium enterprises (SMEs) financing practice and accessing bank loan issues: The Case of Libya. International Journal of Economics and Management Engineering, 6(12), 3715-3720. http: //doi.org/10.5281/zenodo.1084698

Waweru, C., \& Ngugi, K. (2014). Influence of financial management practices on the performance of micro and small enterprises in Kenya. European Journal of Business Management, 1(11), 1-20.

Wood, F., \& Sangster, A. (2012). Business Accounting (12th ed.). Edinburgh: Pearson Education Limited.

World Bank. (2014). Global Financial Development Report 2014: Financial Inclusion. Washington, DC.: World Bank. https://doi.org/10.1596/9780821399859

World Bank. (2018). Improving access to finance for SMEs: Opportunities through credit reporting, secured lending and insolvency practices. World bank group.

Zikmund, W. G. (2003). Business research methods. New York: Thomas South-Western.

\section{Copyrights}

Copyright for this article is retained by the author(s), with first publication rights granted to the journal.

This is an open-access article distributed under the terms and conditions of the Creative Commons Attribution license (http://creativecommons.org/licenses/by/4.0/). 